\title{
EVALUASI DIMENSI UNIT ISTALASI PENGOLAHAN AIR LIMBAH DOMESTIK RUMAH SAKIT dr. ERNALDI BAHAR KOTA PALEMBANG
}

\author{
Yenni Sofyan Mora ${ }^{1}$ Novia $^{2}$, Dedi Setiabudidaya ${ }^{3}$ \\ ${ }^{1}$ Mahasiswa Program Studi Pengelolaan Lingkungan PPS Universitas Sriwijaya \\ ${ }^{2}$ Dosen Program Studi Pengelolaan Lingkungan PPS Universitas Sriwijaya \\ e-mail : yennisofyanmora@yahoo.co.id
}

\begin{abstract}
ABSTRAK
Penelitian ini bertujuan menganalisa karakteristik air limbah domestik serta mengevaluasi kriteria teknis bangunan unit pengolahan air limbah domestik yang ada di RS ERBA apakah sudah memenuhi standar. Dilakukan di wilayah Rumah Sakit dr. Ernaldi bahar yang berlokasi di Jalan Tembus Terminal Km 12 No 2 RT 20 RW 04 Kecamatan Alang-Alang Lebar Kota Palembang dari bulan November 2014 - Maret 2015. Metode Peneliti melaksanakan penelitian pada air limbah domestik, bangunan IPAL domestik dan tangki septik ruang rawat inap menggunakan metode observasional, Metode komparatif (perbandingan) mengacu pada Keputusan Menteri Negara Lingkungan Hidup Nomor : Kep-58/MENLH/12/1995 dan Kriteria Desain bangunan unit pengolahan air limbah berdasarkan pada Kriteria Teknis Prasarana \& Sarana Pengolahan Air Limbah PU. Hasil penelitian menunjukan bahwa kualitas effluen limbah cair IPAL domestik rumah sakit telah memenuhi standar baku mutu limbah cair yang dikeluarkan oleh KepMen LH No.Kep-58/MENLH/12/1995 kecuali untuk parameter amoniak (NH3N) tinggi. debit air limbah melebihi kapasitas tampung pada IPAL domestik dan tangki septik. Kesimpulan dari penelitian ini adalah strategi perencaaan teknis dimensi pada bangunan bak kontrol, IPAL STP Biotech dan Tangki Septik.
\end{abstract}

Kata kunci : Air limbah, Evaluasi IPAL Domestik, Tangki Septik. 


\section{PENDAHULUAN}

Untuk membangun Instalasi Pengolahan Air Limbah (IPAL) di rumah sakit yang sesuai dengan standar memerlukan investasi yang tinggi. Masalah ini seringkali menjadi hambatan bagi kebijakan manajemen rumah sakit. Sebagian besar rumah sakit di Indonesia masih menggunakan pengolahan limbah cair dan sistem tangki septik secara sederhana untuk pengolahan limbah cairnya, Namun ada juga yang telah menggunakan dengan berbagai teknologi untuk menghasilkan kualitas effluen (keluaran) yang telah memenuhi baku mutu. Tangki septik dianggap sebagai cara penampungan tinja yang terbaik padahal sebenarnya masih terjadi pencemaran tanah dan air melalui saluran perembesan karena dalam pelaksanaan operasional dan pemeliharaannya kadang menghadapi beberapa kendala teknis antara lain blower tidak berfungsi, diffuser tersumbat, pompa recycle lumpur aktif tidak berfungsi, parameter amoniak dan fosfat masih tinggi serta timbulnya bau yang dapat mempengaruhi lingkungan.

Air limbah yang dihasilkan oleh sebuah rumah sakit umumnya banyak mengandung bakteri, virus, senyawa kimia dan obatobatan yang dapat membahayakan bagi kesehatan masyarakat sekitar rumah sakit tersebut. Air limbah rumah sakit dr. Ernaldi Bahar yang berasal dari limbah domestik maupun buangan limbah cair klinis umumnya mengandung senyawa polutan organik yang cukup tinggi dan dapat diolah dengan proses pengolahan secara biologis. Sedangkan untuk air limbah rumah sakit yang berasal dari laboratorium biasanya banyak mengandung logam berat. Kalau limbah klinis dialirkan ke dalam proses pengolahan air limbah secara biologis, logam berat tersebut dapat mengganggu proses pengolahannya. Oleh karena itu sebelum dibuang ke saluran umum, limbah dari laboratorium dipisahkan dan ditampung dan dilakukan pengolahan khusus secara kimia-fisika.

Untuk mengolah air limbah klinis maupun domestiknya, Rumah Sakit dr. Ernaldi Bahar Kota Palembang telah membuat 2 Unit Instalasi Pengolahan Air Limbah (IPAL) klinis dan domestik yang telah beroperasi di KM 12 sejak tahun 2011. Air limbah domestik rumah sakit dr. Ernaldi Bahar yang berasal dari air limbah domestik karyawan, dapur, laundry, toilet/kamar mandi pasien (air kotor/black water), wastafel (air bekas/grey water) dan air limpasan dari tangki septik/swage pit dialirkan ke sump pit/bak penampung disalurkan melalui pipa untuk dialirkan kembali menuju bak kontrol dan dialirkan secara gravitasi ke tangki STP Biotech (anoxic chamber, anaerobik chamber, aerobic chamber, sedimentasi chamber, aeration chamber) untuk dilakukan pengolahan secara biologis sebelum dibuang ke saluran umum.

Penelitian ini menyajikan karakteristik air limbah domestik RS ERBA, Evaluasi Unit Pengolahan Air limbah domestik dan tangki septik ruangan rawat inap RS ERBA yang Berdasarkan hasil observasi lapangan, debit air limbah yang diolah dengan IPAL yang ada melebihi kapasitas tampung terbukti dengan meluapnya air limbah dari tangki septik ruangan rawat inap dan IPAL domestik, yang akan berdampak membahayakan manusia dan lingkungan disekitarnya. Evaluasi Penelitian ini di harapkan dapat menjadi masukan bagi pihak RS ERBA agar dapat mengatasi permasalahan yang ada di bangunan unit pengolahan air limbah domestik RS ERBA dan menjadi dasar untuk penelitian serupa dalam perencanaan desain bangunan pengolahan air limbah untuk rumah sakit.

\section{METODOLOGI PENELITIAN}

\section{Alat dan Bahan}

Alat yang digunakan adalah analisa air limbah yaitu $\mathrm{pH}$ meter, Winkler Azide, Close Reflux Gravimetrik, Spectrofotometer dan Flow meter jenis elektromagnetic untuk pengukuran debit air limbah. Objek yang diteliti adalah air limbah, IPAL domestik dan tangki septik ruangan rawat inap RS Ernaldi Bahar Kota Palembang.

\section{Prosedur Kerja}

Pengamatan lapangan dilakukan dari bulan November 2014 - Maret 2015. Metode Peneliti melaksanakan penelitian pada air limbah domestik, bangunan IPAL domestik 
dan tangki septik ruang rawat inap menggunakan metode observasional, Metode komparatif (perbandingan) mengacu pada Keputusan Menteri Negara Lingkungan Hidup Nomor : Kep-58/MENLH/12/1995 dan Kriteria Desain bangunan unit pengolahan air limbah berdasarkan pada Kriteria Teknis Prasarana \& Sarana Pengolahan Air Limbah PU. Pengambilan sampel menggunakan cara sampel sesaat (grab sampel) merupakan volume sampel yang diambil langsung dari sumber yang akan diteliti kualitas air limbahnya. titik pengambilan sampel yaitu sampel air limbah yang berasal dari inlet dan outlet IPAL domestik. Pemeriksaan analisis sampel dilakukan di Laboratorium BTKL Palembang.

Evaluasi Unit Pengolahan Air Limbah Domestik RS ERBA dengan menghitung fluktuasi debit harian air limbah domestik yang dihasilkan oleh rumah sakit dengan menggunakan rumus dan alat flow meter jenis elektromagnetik, mengevaluasi kriteria teknis bangunan unit pengolahan air limbah domestik dengan metode observasional dan metode komparatif (perbandingan) berdasarkan Kriteria Teknis Prasarana dan Sarana Pengolahan Air Limbah PU dan literatur lainnya serta melakukan strategi perencaaan teknis untuk mengatasi debit air limbah yang melebihi kapasitas tampung pada IPAL domestik

Evaluasi tangki septik ruangan rawat inap RS ERBA dengan menghitung debit air limbah tangki septik yang dihasilkan oleh ruangan rawat inap, mengevaluasi kriteria teknis bangunan tangki septik dengan metode observasional dan metode komparatif (perbandingan) berdasarkan Kriteria Teknis Prasarana dan Sarana Pengolahan Air Limbah PU dan melakukan strategi perencaaan teknis untuk mengatasi debit air limbah yang melebihi kapasitas tampung pada tangki septik ruangan rawat inap.

\section{HASIL DAN PEMBAHASAN}

Dari hasil penelitian karakteristik air limbah RS ERBA yang dilakukan pada Tahun 2014 dan Tahun 2015 kualitas effluen limbah cair IPAL domestik rumah sakit telah memenuhi standar baku mutu limbah cair yang dikeluarkan oleh KepMen LH No.Kep58/MENLH/12/1995, namun untuk parameter amoniak $\left(\mathrm{NH}_{3} \mathrm{~N}\right)$ melebihi baku mutu limbah cair. Tingginya kadar amoniak disebabkan oleh aerasi yang kurang atau lumpur yang tidak pernah dibuang keluar, perlu dilakukan pengolahan lumpur lanjutan.

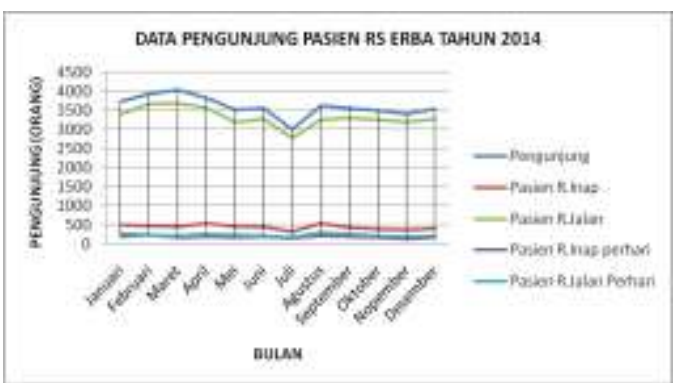

Gambar 1. Data Pengunjung Pasien RS ERBA Tahun 2014

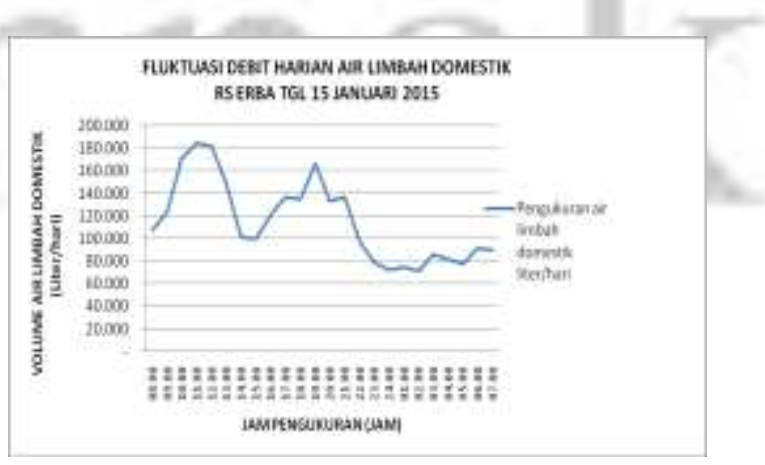

Gambar 2. Fluktuasi debit harian air limbah domestik tanggal 15 Februari 2015

Evaluasi instalasi pengolahan air limbah domestik RS ERukan dengan metode observasi pengamatan kualitatif secara langsung dan metode komparatif

\section{a. Bak Kontrol}

Bak ini adalah sebagai proses awal untuk menyaring kotoran/sampah yang besar yang berpotensi mengganggu proses pengolahan. bak kontrol ini dilengkapi dengan screen yang terbuat dari fibreglass. Air limbah yang masuk ke bak kontrol ini akan mengalir secara gravitasi ke tangki STP Biotech. 
- Kapasitas Pengolahan : 171.450 liter/hari $=171 \mathrm{~m}^{3} / \mathrm{hari}=7,14 \mathrm{~m}^{3} / \mathrm{jam}=118$ liter/menit.

Dimensi Bak Eksisting :

- Panjang bak (p)

$: 1,2 \mathrm{~m}$

- Lebar bak (l)

$: 1,2 \mathrm{~m}$

- Tinggi bak (t)

$: 1 \mathrm{~m}$

- Ruang bebas (free board)

$: 0,2 \mathrm{~m}$

- Volume efektif

$: 1,68 \mathrm{~m}^{3}$

- Tebal dinding

$: 15 \mathrm{~cm}$

- Waktu tinggal (td)

$: \pm 2 \mathrm{jam}$

\section{Evaluasi Bak Kontrol}

Dalam Bak Kontrol dipasang screen dari kawat baja tahan karat, fungsi dari bak kontrol adalah mencegah limbah padat (plastik, kaleng, kayu, dsb) agar tidak masuk ke dalam unit pengolahan limbah. Bangunan ini disudah dilengkapi dengan penutup bak. Ukuran dimensi bak unit kontrol dengan panjang : $1,00 \mathrm{~m}$, lebar : $1,20 \mathrm{~m}$ dan kedalaman bak : 1,20 m volume bak : 1,2 $\mathrm{m}^{3}$ belum memenuhi kriteria kontruksi karena volume bak yang diperlukan seharusnya

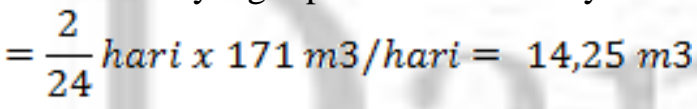

Dimensi bak direncanakan :

- Panjang bak (p)

$$
: 3 \mathrm{~m}
$$

- Lebar bak (1)

$: 2,5 \mathrm{~m}$

- Tinggi bak (t)

$: 2 \mathrm{~m}$

- Ruang bebas (free board)

- Volume efektif

$: 0,2 \mathrm{~m}$

- Tebal dinding

$: 14 \mathrm{~m}^{3}$

- Waktu tinggal (td)

$: 15 \mathrm{~cm}$

$: \pm 2 \mathrm{jam}$

Untuk mengevaluasi waktu tinggal (td) apakah sudah sesuai maka kita cek

$t d($ jam $)=\frac{\text { vol efektif }(\mathrm{m} 3)}{\text { debit }(\mathrm{m} 3 / \mathrm{hr})}=\frac{14,25 \mathrm{~m} 3}{171 \mathrm{~m} 3 / \mathrm{hr}}=0,08 \mathrm{ha}$

Jadi waktu tinggal (td) didalam bak 2 jam, sesuai kriteria.

Hasil pengamatan di lapangan sering ditemui sampah-sampah kasar berupa plastik atau dedaunan karena bar screen pada saluran inlet instalasi pengolahan tidak berfungsi dengan baik seharusnya aliran air lancar dan sampah tidak ikut terbawa, hal ini tentu saja dapat mempengaruhi kinerja unit pengolahan. Sampah di dalam bak ini sebaiknya rutin diambil setiap 1 minggu sekali agar tidak terjadi penyumbatan sehingga aliran air limbah lancar.

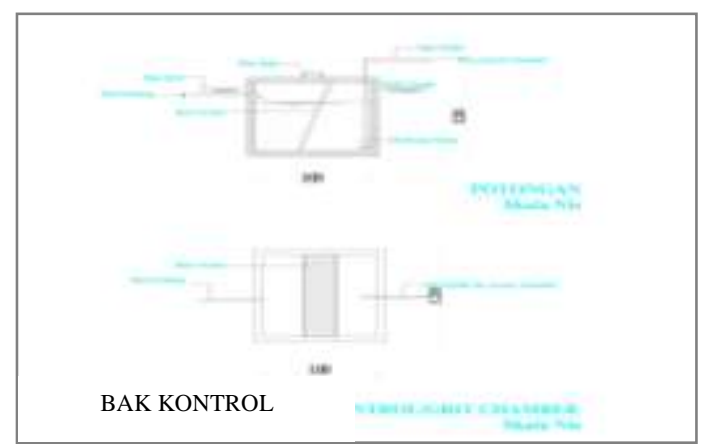

Gambar 3. Rencana Dimensi Bak Kontrol

\section{b. IPAL Domestik}

Untuk pengolahan limbah domestik RS ERBA ditanam STP Biotech sebanyak 2 (dua) tangki yaitu 1 tangki anaerobik dan 1 tangki aerobik model silinder horizontal dipasang secara paralel di dalam bak cor beton di atas lahan berukuran $\mathrm{L}=30 \mathrm{~m} \mathrm{P}=$ $10 \mathrm{~m}$, material body fibreglass, Pipa PVC, return sludge dan airlift dengan sistem blower dengan ukuran dimensi luar untuk 1 tangki STP Biotech panjang tangki $11 \mathrm{~m}$, diamater 2,70 m kapasitas 62.000 liter.

1 tangki anaerobic terdiri dari 3 kompartemen yaitu anoxic chamber, anaerobic chamber 1st, anaerobic chamber 2nd yaitu pengolahan anaerobic dengan sistem instalasi pengolahan air limbah tanpa menggunakan instalasi pipa dan mesin blower, media cell A honey com.

1 tangki aerobic terdiri dari 4 kompartemen yaitu aerobic chamber 1st, aerobic chamber 2nd yaitu pengolahan aerobic dengan sistem instalasi pengolahan air limbah menggunakan instalasi pipa dan mesin

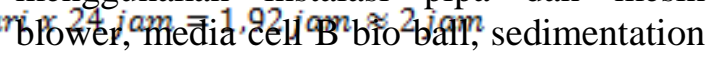
chamber serta clorination chamber. Influent $\mathrm{BOD}=300, \mathrm{COD}=300, \mathrm{SS}=200 \mathrm{mg} / \mathrm{L}$, Effluent BOD $=20-30, \mathrm{COD}=40-50, \mathrm{SS}=$ $50-60 \mathrm{mg} / \mathrm{L}$.

\section{Evaluasi IPAL Domestik}

Berdasarkan hasil pengamatan di lapangan debit air limbah IPAL Biotech melebihi kapasitas tangki terlihat dengan meluapnya air limbah tersebut. Dengan ukuran 1 tangki STP Biotech tinggi $11 \mathrm{~m}$ diamater 2,70 m, maka kapasitas tangki diperoleh 62.949 liter x 2 tangki $=125.898$ liter $/$ hari berarti 
volume eksisting IPAL Biotech ini tidak memenuhi untuk kebutuhan debit rata-rata air limbah domestik RS ERBA (Q) sebesar 171.450 liter $/$ hari $=171 \mathrm{~m}^{3} /$ hari $=7,14$ $\mathrm{m}^{3} / \mathrm{jam}=118$ liter/menit. Seharusnya menggunakan tangki STP Biotech yang berukuran dimensi luar panjang $11 \mathrm{~m}$ dengan diamater $3 \mathrm{~m}$.

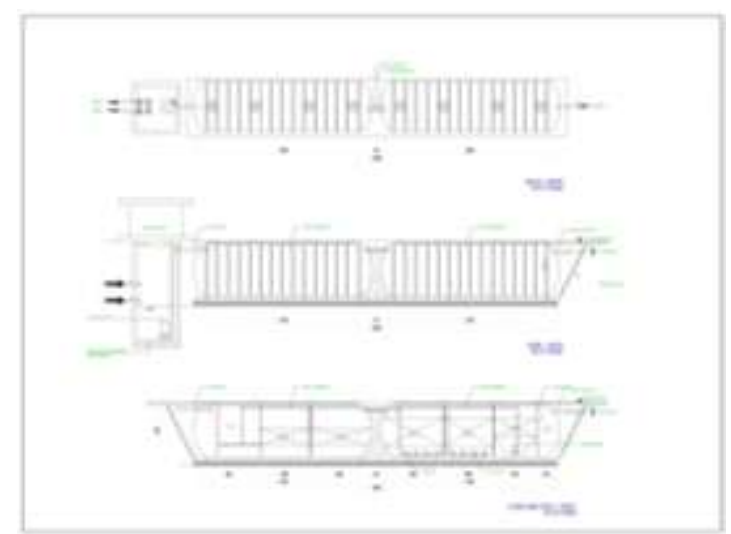

Gambar 4. Rencana IPAL STP Biotech

- Tangki Anaerobic

Pada pengolahan anaerobik harus selalu tertutup (tidak ada) oksigen. arah aliran dari atas ke dan bawah ke atas. Kriteria teknis untuk tangki anaerobik yaitu :

- Waktu tinggal (retention time) ratarata $=6-8$ jam

- Tinggi ruang lumpur $=0,5 \mathrm{~m}$

- Tinggi bed media pembiakan mikroba $=0,9-1,5 \mathrm{~m}$

- $\quad$ Tinggi air diatas bed media $=20 \mathrm{~cm}$

- Beban BOD persatuan permukaan media $=5-30 \mathrm{~g} \mathrm{BOD} / \mathrm{m}^{2}$.hari

Evaluasi :

Debit $(\mathrm{Q})$ air limbah $=171.450$ liter $/$ hari $=$ $171 \mathrm{~m}^{3} /$ hari $=7,14 \mathrm{~m}^{3} /$ jam $=118$ liter $/$ menit . BOD Masuk $=240 \mathrm{mg} / \mathrm{L}$

Efisiensi $=80 \%$

BOD Keluar $=80 \mathrm{mg} / \mathrm{L}$

Ditetapkan beban BOD standar yang

digunakan $=4 \mathrm{~kg} \mathrm{BOD} / \mathrm{m}^{3}$.hari

Beban BOD di dalam air limbah $=171$

$\mathrm{m}^{3} /$ hari $\times 240 \mathrm{~g} / \mathrm{m}^{3}=41,04 \mathrm{gr} / \mathrm{hari}=41$

$\mathrm{kg} / \mathrm{hari}$

Volume media yang diperlukan $=\frac{41 \mathrm{~kg} / \mathrm{hr}}{4 \mathrm{~kg} / \mathrm{m} 3 \text {.hari }}=10,25 \mathrm{~m} 3$

Volume media $=75 \%$ dari volume tangki anaerobic

Volume tangki anaer abfk yang diperiwkan $=\frac{100}{78} \times 10,25 \mathrm{~m} 3=13 \mathrm{~m} 3$
Untuk mengevaluasi waktu tinggal (td) apakah sudah sesuai maka kita cek waktu tinggal didalam reaktor anaerobic

$=\frac{13 \mathrm{~m} 3}{171 \mathrm{~m} 3 / \text { hari }} \times 24 \mathrm{jam} / \mathrm{hr}=1,8 \mathrm{~m} 3 \approx 2 \mathrm{jam}$

Jadi waktu tinggal didalam bak 2,7 jam, tidak sesuai kriteria karena waktu tinggal rata2 6-8 jam.

Pengolahan pada tangki Anaerobic terdiri dari 3 kompartemen

- Anoxic Chamber, dilengkapi perfored screen dan manhole. Dimensi ukuran panjang $=4,00 \mathrm{~m}$, Diameter $=2,70 \mathrm{~m}$

- Anaerob Chamber, tinggi tangki anaerobic $1=3,00 \mathrm{~m}$, tangki anaerobic 2 $=4,00 \mathrm{~m}$, diameter : $2,70 \mathrm{~m}$, Media Cell A type fixed media sheet (batu kerikil,batu apung,plastik polytilen) kapasitas $140 \mathrm{~m}^{2} / \mathrm{m}^{3}$ material PVC.

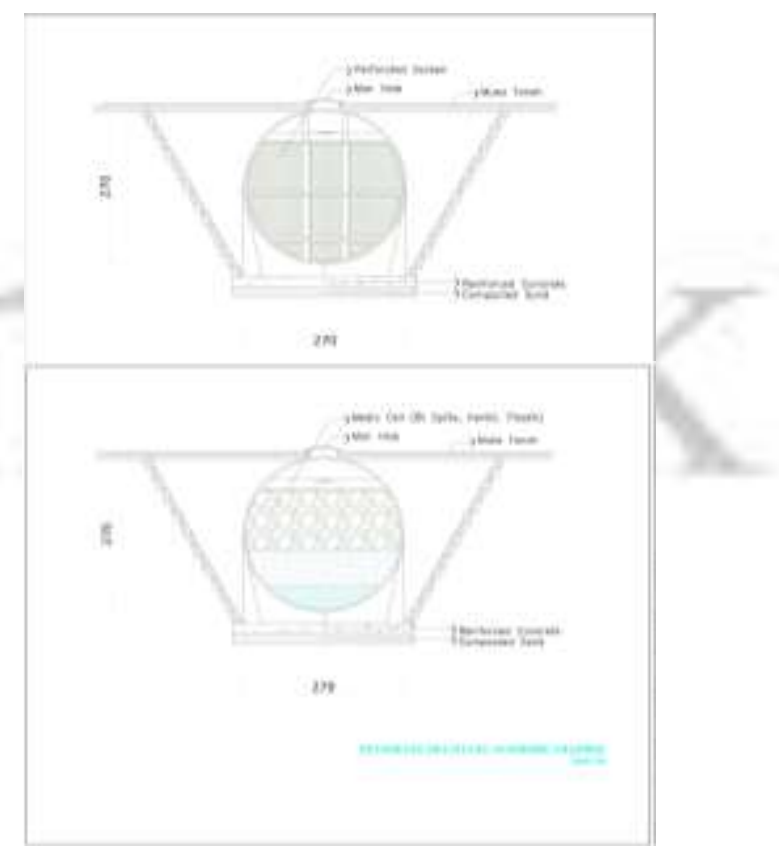

Gambar 5. Penampang Anoxic dan Anaerobik

- Tangki Aerobic

Pada pengolahan aerob chamber, memerlukan pasokan oksigen terlarut secara kontinu untuk menurunkan kandungan bahan-bahan organik di dalam air limbah. Kriteria teknis untuk tangki aerobik yaitu :

- Waktu tinggal (retention time) ratarata $=6-8$ jam

- $\quad$ Tinggi ruang lumpur $=0,5 \mathrm{~m}$

- Tinggi bed media pembiakan mikroba $=1,2 \mathrm{~m}$

- Tinggi air diatas bed media $=20 \mathrm{~cm}$ 
- Beban BOD persatuan permukaan media $=5-30 \mathrm{~g} \mathrm{BOD} / \mathrm{m}^{2}$.hari

Evaluasi :

Debit $(\mathrm{Q})$ air limbah $=171.450$ liter $/$ hari $=$ $171 \mathrm{~m}^{3} /$ hari $=7,14 \mathrm{~m}^{3} /$ jam $=118$ liter $/$ menit. BOD Masuk $=35 \mathrm{mg} / \mathrm{L}$

Efisiensi $=60 \%$

BOD Keluar $=17 \mathrm{mg} / \mathrm{L}$

Beban BOD di dalam air limbah $=171$

$\mathrm{m}^{3} /$ hari $\times 35 \mathrm{~m}^{3} /$ hari $=5.985 \mathrm{gr} /$ hari $=5.98$ $\mathrm{kg} / \mathrm{hari}$

Jumlah BOD yang dihilangkan : $0.6 \times 5.98=$ $3,58 \mathrm{~kg} / \mathrm{hari}$

Beban BOD per volume media yang digunakan $=0,5 \mathrm{~kg} / \mathrm{m}^{3}$.hari

Volume media yang diperlukan $=5,98 / 0.5$

$=11,96 \mathrm{~m}^{3}$

Volume media $=60 \%$ dari volume tangki aerob $=100 / 60 \times 11,96=19,93 \mathrm{~m}^{3}$

Untuk mengevaluasi waktu tinggal (td) apakah sudah sesuai maka kita cek

Waktu Tinggal $=19,93 / 171 \times 24$ jam $=2,7$ jam

Jadi waktu tinggal (td) didalam bak 2,7 jam, tidak sesuai kriteria seharusnya 6-8 jam. Pengolahan pada tangki Aerobik terdiri dari 4 kompartemen

\section{- Aerob Chamber}

Tinggi tangki aerobik $1 \mathrm{P}=3 \mathrm{~m}$, tangki aerobik $2 \mathrm{P}=4 \mathrm{~m}$, diameter : 2,70 m, Media Cell B Bio Ball material HDPE kapasitas $180 \mathrm{~m}^{2} / \mathrm{m}^{3}$. Berdasarkan hasil penelitian sistem pada aerobik chamber (blower/aerator) tidak berjalan dgn baik, sehingga kerja mikroba pengurai lumpur tidak maksimal, sehingga volume pertumbuhan lumpur meningkat yang akan memenuhi bak sedimentasi.

- Sedimentasi Chamber

Panjang $=2,50 \mathrm{~m}$ dan diameter $2,70 \mathrm{~m}$, media honey comb type hexagonal kapasitas $120 \mathrm{~m}^{2} / \mathrm{m}^{3}$ material FRP. Waktu tinggal ratarata 2-5 jam. Butiran halus dan partikel kasar dari lumpur yang terlarut dalam air limbah akan diendapkan pada bangunan pengendapan ini karena diharapkan air limbah yang keluar dari bangunan pengendapan ini sudah tidak mengandung benda-benda kasar, pasir kasar dan pasir halus, namun berdasarkan hasil pengamatan backwash (pompa lumpur) tidak bekerja dengan baik, sehingga lumpur dalam bak sedimentasi tidak tergedradasi dengan baik sehingga ruang bak cepat penuh, akibatnya terjadi luapan lumpur. Sebaiknya lumpur dalam bak ini harus dilakukan pemeriksaan dan dibersihkan secara berkala sehingga meminimalkan terjadinya luapan.

\section{- Clorination Chamber}

Dimensi panjang $=2,50 \mathrm{~m}$ dan diameter 2,70 m, ditambahkan senyawa khlor (kaporit dalam bentuk tablet) 500 gram/hari berfungsi untuk mengkontakkan khlorine dengan air hasil pengolahan agar mikroorganisme patogen yang ada di dalam air dapat dimatikan. Bak klorinasi ini dipasang atau disambungkan pada pipa outlet air limbah. Namun berdasarkan hasil penelitian air limbahnya masih tinggi kadar amoniak, ini disebabkan oleh aerasi yang kurang atau lumpur yang tidak pernah dibuang keluar perlu dilakukan pengolahan lumpur lanjutan. Perhitungan Dosis Khlorine

$$
\begin{aligned}
& \mathrm{A}=\frac{B x C}{1.000 .000} \\
& \mathrm{~A}=\frac{5 \text { ppm } x 171.450 \text { liter } / \mathrm{hari}}{1.000 .000}=0,86 \mathrm{~kg} \\
& / \text { hari }=860 \mathrm{gram} / \mathrm{hari}=35,8 \mathrm{gram} / \mathrm{jam}
\end{aligned}
$$

Jadi kebutuhan klorin yang digunakan yaitu sebanyak 860 gram/hari klorin tidak sesuai dengan kriteria karena pembubuhan klorin pada Clorine chamber sebanyak 500 gram/hari.

- Kebutuhan oksigen didalam tangki aerob sebanding dengan jumlah BOD yang dihilangkan, Jadi kebutuhan teoritis = jumlah BOD yang dihilangkan $=3,58$ $\mathrm{kg} / \mathrm{hari}$

Faktor keamanan ditetapkan $\pm 2,0$, Maka kebutuhan oksigen teoritis $=2 \times 3,58$ $\mathrm{kg} / \mathrm{hari}=7,16 \mathrm{~kg} / \mathrm{hr}$, Temperatur udara rata-rata $=28^{\circ} \mathrm{C}=1,1725 \mathrm{~kg} / \mathrm{m}^{3}$

Diasumsikan jumlah oksigen didalam udara 23,2 \% sehingga jumlah kebutuhan oksigen teoritis $=\frac{7,16 \mathrm{~kg} / \mathrm{hr}}{1,1725 \mathrm{~kg} / \mathrm{m} 3 \times 0,232 \mathrm{~g} \mathrm{O2} / \mathrm{g} \text { udara }}=26,3 \mathrm{~m} 3 / \mathrm{hr}$

efisiensi difuser $=3 \%$

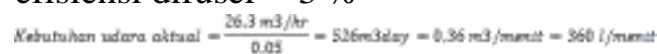
Jika kapasitas blower adalah 100 liter/menit dan terdiri dari 2 unit maka transfer total udara $=200$ liter $/$ menit 


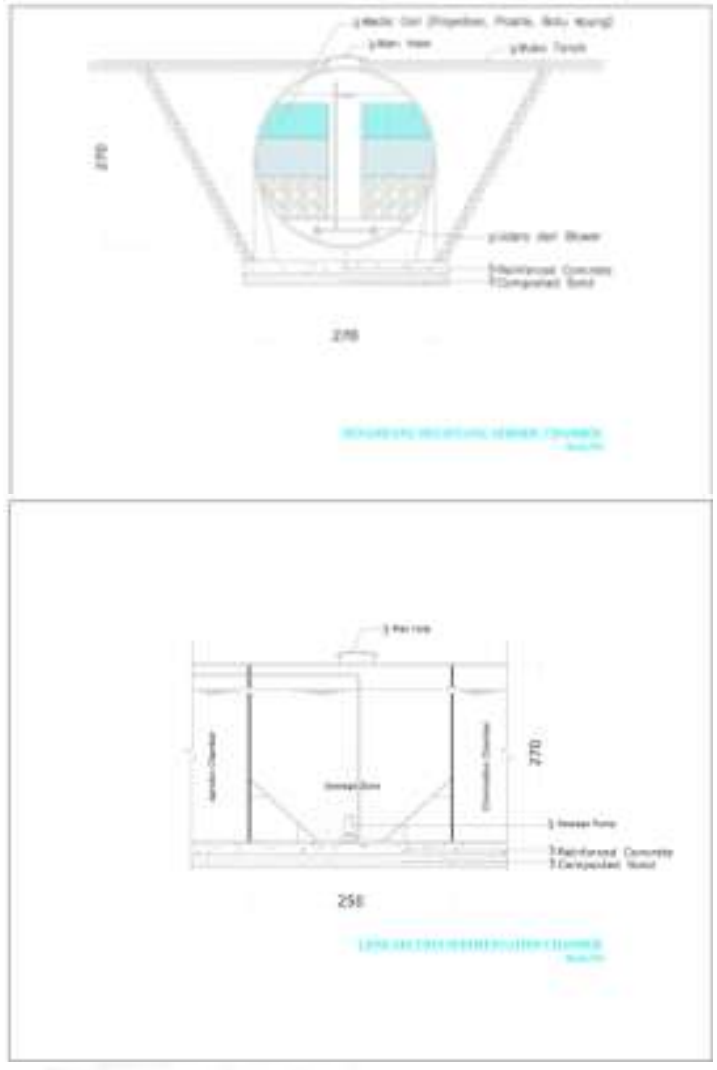

Gambar 6. Penampang aerobik dan sedimentasi chamber

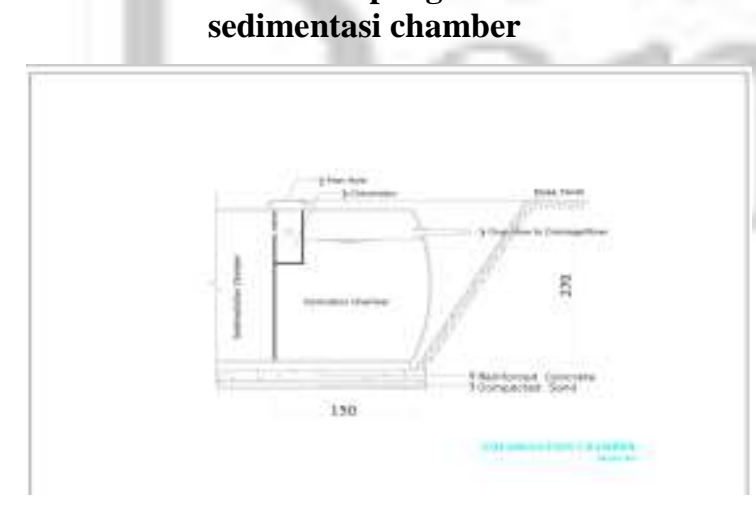

Gambar 7. Penampang aeration chamber

Dari hasil evaluasi penelitian IPAL domestik RS ERBA bahwa unit IPAL terdiri dari unit kontrol, tangki anaerobic (anoxic chamber, anaerobic chamber), tangki aerobic (aerobic chamber, klorinasi chamber, sedimentation chamber). Dengan menggunakan metode perbandingan (storet) menyatakan bahwa hasil penelitian kualitas air limbah domestik memenuhi standar hanya untuk parameter ammonia $\left(\mathrm{NH}_{4}\right)$ yang melebihi baku mutu limbah cair berdasarkan KepMen LH No.Kep-58/MENLH/12/1995
Hasil evaluasi dimensi bangunan IPAL domestik membandingkan dengan kriteria teknis prasarana dan sarana pengolahan air limbah PU (2006) dan Said (2006), bahwa dimensi bangunan IPAL tidak sesuai kriteria sehingga melakukan rekomendasi perbaikan pada dimensi bak unit kontrol semula ukuran panjang : $1,00 \mathrm{~m}$, lebar : $1,20 \mathrm{~m}$ dan kedalaman : $1,20 \mathrm{~m}$ volume bak : $1,2 \mathrm{~m}^{3}$ direkomendasikan seharusnya dimensi bak panjang $=3 \mathrm{~m}$, lebar $=2,5 \mathrm{~m}$, tinggi $=2 \mathrm{~m}$, ruang bebas (free board) $0,2 \mathrm{~m}$, volume efektif $14 \mathrm{~m} 3$, tebal dinding $15 \mathrm{~cm}$, waktu tinggal (td) \pm 2 jam sesuai kriteria. Untuk tangki anaerobik dan tangki aerobik waktu tinggal (td) tidak memenuhi kriteria yang seharusnya 6-8 jam, waktu tinggal yang terlalu cepat sangat mempengaruhi debit air limbah karena desakan debit yang terlalu besar akan membuat debit air limbah meluap keluar.

Hasil yang sama didapatkan pada penelitian Maryam (2014), IPAL RS dr. Rubini Mempawah terdiri dari unit kontrol, unit pengendap I, unit pengurai anaerob, unit $U p$ Flow Filter/aerob, unit klorinasi, unit pengendap akhir dan unit stabilisasi. Dengan menggunakan metode perbandingan (storet) menyatakan bahwa hasil penelitian kualitas air limbah RS dr. Rubini Mempawah untuk parameter COD, TSS, Ammonia $\left(\mathrm{NH}_{4}\right)$ melebihi baku mutu limbah cair berdasarkan KepMen LH No.Kep-58/MENLH/12/1995 dan mengevaluasi desain bangunan IPAL membandingkan dengan kriteria teknis prasarana dan sarana pengolahan air limbah PU (2006) dan Said (2006), bahwa dimensi bangunan IPAL tidak sesuai kriteria pada unit pengurai anaerob dan unit up flow filter sehingga melakukan rekomendasi perbaikan pada unit instalasi pengolahan air limbah yaitu perancangan ulang semula dimensi unit anaerob $\mathrm{P}=3,30 \mathrm{~m}, \mathrm{~L}=3,30 \mathrm{~m}, \mathrm{~T}=$ $2,60 \mathrm{~m}$ diubah dimensi menjadi $\mathrm{P}=3,5 \mathrm{~m}, \mathrm{~L}$ $=3,5 \mathrm{~m}, \mathrm{~T}=3 \mathrm{~m}$ biofilter sarang tawon dan semula unit up flow filter $\mathrm{P}=7,7 \mathrm{~m}, \mathrm{~L}=$ $12,08 \mathrm{~m}, \mathrm{~T}=3 \mathrm{~m}$ diubah dimensi $\mathrm{P}=21,16$ $\mathrm{m}, \mathrm{L}=4 \mathrm{~m}, \mathrm{~T}=2 \mathrm{~m}$ media pelekat sarang tawon.

Setelah dibandingkan hasil evaluasi penelitian RS ERBA yang didapatkan tidak jauh berbeda pada penelitian yang dilakukan maryam (2014). Pada penelitian Maryam 
(2014) unit pengolahan IPAL terdiri unit kontrol, unit pengendap I, unit pengurai anaerob, unit Up Flow Filter/aerob, unit klorinasi, unit pengendap akhir dan unit stabilisasi namun untuk IPAL domestik RS ERBA terdiri dari unit kontrol, tangki anaerobic (anoxic chamber, anaerobic chamber), tangki aerobic (aerobic chamber, klorinasi chamber, sedimentation chamber). Menurut kriteria teknis prasarana dan sarana pengelolaan air limbah (PU, 2006) pengolahan air limbah di IPAL pada umumnya terdiri dari pengolahan fisik (screen dan grit chamber), unit pengendap I, unit anaerobik, unit aerobik, unit aerasi, unit pengendap II, unit stabilisasi.

IPAL domestik RS ERBA sebaiknya dilengkapi unit sedimentasi I sebagai pengolahan awal sehingga overflow tidak terlalu cepat sehingga waktu tinggal untuk pengolahan bisa lebih optimal karena fungsi utama bak pengendap I adalah mengendapkan partikel discrete, menurunkan konsentrasi BOD/COD dalam aliran sehingga membantu menurunkan beban pengolahan biologis pada tahapan pengolahan berikutnya dan dapat mengendapkan (50-70)\% padatan yang tersuspensi (suspended solid) dan mengurangi (30-40)\% BOD. Dimensi untuk bak pengendap I dengan ratio $\mathrm{P} / \mathrm{L}=4: 1$ kedalaman $3 \mathrm{~m}$, waktu tinggal (retention time) rata-rata $=3-5$ jam dengan beban permukaan $=20-30 \mathrm{~m}^{3} / \mathrm{m}^{2}$.hari $($ JWWA $)$. Selain itu perlu unit greese trap/pemisah lemak utuk menyaring limbah yang berasal dari limbah dapur dan laundry.

\section{c. Tangki septik}

Data Eksisting

- Debit Tangki Septik : $4,8 \mathrm{~m}^{3} / \mathrm{jam}$

- Panjang (p) : $1,20 \mathrm{~m}$

- Lebar (l) : : 1,50 m

- Tinggi ( $\mathrm{t}) \quad: 1,50 \mathrm{~m}$

\section{Evaluasi :}

Berdasarkan evaluasi di lapangan menunjukkan bahwa air limbah dari tangki septik ruangan rawat inap debitnya melebihi kapasitas tampung sehingga meluap dikarenakan tidak memenuhi syarat konstruksi ukuran panjang, lebar dan kedalaman tangki tidak sesuai syarat teknis yaitu $1,20 \times 1,50 \times 1,50 \mathrm{~m}$ karena ukuran yang dianjurkan untuk ruang rawat yang berkapasitas \pm 50 TT, seharusnya menggunakan tangki septik berukuran panjang $=2,60 \mathrm{~m}$ lebar $=1,30 \mathrm{~m}$ kedalaman + freeboard $=1,8 \mathrm{~m}$ dengan kapasitas tangki septik berkapasitas $4,8 \mathrm{~m} 3$ dengan waktu tinggal selama 3 hari (PU, 2002)

Faktor lainnya antara lain tidak ada saluran perembesan jadi efluen langsung dibuang ke badan air dalam keadaan yang membahayakan kesehatan, tidak ada sekat sesudah influen dan sebelum efluen sehingga efluen dapat tersumbat tinja padat, kemiringan dasar tangki tidak cukup dan hanya mempunyai 1 ruang lumpur maka pada waktu menyedot lumpur akan berbau karena yang tersedot adalah lumpur yang belum membusuk dengan sempurna.

Tangki septik di ruangan rawat inap yang meluap mengakibatkan pencemaran tanah dan air melalui saluran perembesan karena dalam pelaksanaan operasional dan pemeliharaannya menghadapi beberapa kendala teknis antara lain blower tidak berfungsi, diffuser tersumbat, pompa recycle lumpur aktif tidak berfungsi, parameter amoniak masih tinggi serta timbulnya bau yang mempengaruhi lingkungan.

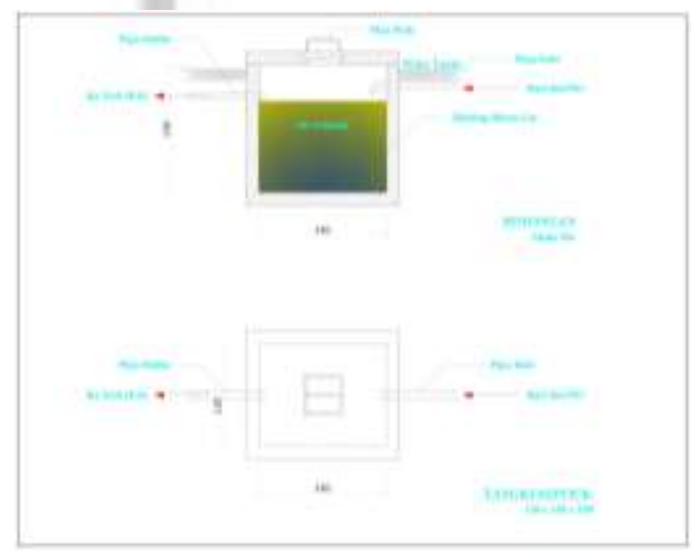

Gambar 8. Tangki Septik 


\section{SIMPULAN}

Dari hasil penelitian dan pembahasan yang telah dilakukan, maka di dapat diambil kesimpulan sebagai berikut :

1. Air limbah domestik RS ERBA yang berasal dari air limbah domestik karyawan, dapur, laundry, toilet/kamar mandi pasien, wastafel dan air limpasan dari tangki septik dialirkan ke bak penampung disalurkan melalui pipa untuk dialirkan kembali menuju bak kontrol dan dialirkan secara gravitasi ke tangki STP Biotech (anoxic chamber, anaerobik chamber, aerobic chamber, sedimentasi chamber, aeration chamber) untuk dilakukan pengolahan secara biologis sebelum dibuang ke saluran umum.

2. Pada Tahun 2014 dan 2015 berdasarkan hasil penelitian, efluen limbah cair IPAL domestik rumah sakit ERBA berdasarkan KepMen LH No.Kep-58/MENLH/12/1995, dari hasil pengujian air limbah tersebut semua parameter telah memenuhi persyaratan baku mutu air limbah, namun untuk parameter amoniak $\left(\mathrm{NH}_{3} \mathrm{~N}\right)$ melebihi baku mutu limbah cair, tingginya kadar amoniak disebabkan oleh aerasi yang kurang atau lumpur yang tidak pernah dibuang keluar atau perlu dilakukan pengolahan lumpur lanjutan.

3. IPAL STP Biotech eksisting ditanam 2 tangki silinder horizontal dipasang secara paralel di dalam bak cor beton di atas lahan berukuran $\mathrm{L}=30 \mathrm{~m} \mathrm{P}=$ $10 \mathrm{~m}$, material body fibreglass, pipa PVC, return sludge dan airlift dengan sistem blower dengan ukuran dimensi luar untuk 1 tangki STP Biotech tinggi tangki $11 \mathrm{~m}$, diamater $2,70 \mathrm{~m}$ kapasitas 62.000 liter. 1 tangki aerobic terdiri dari 3 kompartemen yaitu anoxic chamber, aerobic chamber 1st, an aerobic chamber 2 nd media cell A honey com, 1 tangki aerobic terdiri dari 4 kompartemen yaitu aerobic chamber 1st, aerobic chamber 2nd, sedimentation chamber serta clorination chamber media cell B bio ball. Debit limbah cair rumah sakit ERBA sebesar $171 \mathrm{~m}^{3} /$ hari.
Seharusnya menggunakan tangki STP Biotech yang berukuran dimensi luar panjang $11 \mathrm{~m}$ dengan diamater $3 \mathrm{~m}$.

4. Ukuran dimensi bak unit kontrol dengan $\mathrm{P}: 1,00 \mathrm{~m}, \mathrm{~L}: 1,20 \mathrm{~m}$ dan $\mathrm{h}$ : $1,20 \mathrm{~m}$ volume bak : $1,2 \mathrm{~m}^{3}$ belum memenuhi kriteria kontruksi karena volume bak yang diperlukan seharusnya dimensi bak direncanakan $: \mathrm{P}=3 \mathrm{~m}, \mathrm{~L}=2,5 \mathrm{~m}, \mathrm{~h}=2 \mathrm{~m}$, ruang bebas (free board) $0,2 \mathrm{~m}$, volume efektif : $14 \mathrm{~m} 3$, tebal dinding $15 \mathrm{~cm}$, Waktu tinggal (td) \pm 2 jam sesuai kriteria. Untuk tangki anaerobik dan tangki aerobik waktu tinggal (td) tidak memenuhi kriteria yang seharusnya 68 jam, waktu tinggal yang terlalu cepat sangat mempengaruhi debit air limbah karena desakan debit yang terlalu besar akan membuat debit air limbah meluap keluar. Dosis clorine yang dibubuhkan semula 500 gram dalam Chlorination chamber seharusnya 860 gram/hari.

5. Berdasarkan hasil pengamatan backwash (pompa lumpur) tidak bekerja dengan baik, lumpur dalam bak sedimentasi tidak tergedradasi dengan baik sehingga ruang bak cepat penuh, akibatnya terjadi luapan lumpur. air limbahnya masih tinggi kadar amoniak, ini disebabkan oleh aerasi yang kurang atau lumpur yang tidak pernah dibuang keluar perlu dilakukan pengolahan lumpur lanjutan. Sering ditemui sampahsampah kasar berupa plastik atau dedaunan karena bar screen pada saluran inlet instalasi pengolahan tidak berfungsi dengan baik seharusnya aliran air lancar dan sampah tidak ikut terbawa, hal ini tentu saja dapat mempengaruhi kinerja unit pengolahan.

6. Air limbah dari tangki septik ruangan rawat inap meluap dikarenakan tidak memenuhi syarat konstruksi ukuran panjang, lebar dan dalamnya tangki tidak sesuai syarat yaitu $1,20 \mathrm{x} 1,50 \mathrm{x}$ 1,50 m karena ukuran yang dianjurkan untuk ruang rawat yang berkapasitas \pm 50 TT, seharusnya menggunakan tangki septik berukuran panjang = $2,60 \mathrm{~m}$ lebar $=1,30 \mathrm{~m}$ kedalaman + freeboard $=1,8 \mathrm{~m}$ dengan kapasitas 
tangki septik berkapasitas $4,8 \mathrm{~m}^{3}$ dengan waktu tinggal selama 3 hari.

\section{DAFTAR PUSTAKA}

Departemen Kesehatan RI. 1994. Pedoman Sanitasi Rumah Sakit di Indonesia. Direktorat Jenderal PPM \& PLP dan Direktorat Jenderal Bina Pelayanan Medik, Jakarta

Departemen Kesehatan RI. 2006. Pedoman Pelaksanaan Pengolahan Limbah Padat dan Limbah Cair di Rumah Sakit. Direktorat Bina Pelayanan Medik Spesialistik. Jakarta

Maryam. 2014. Evaluasi Dimensi Instalasi Pengolahan Air Limbah Rumah Sakit Umum Daerah Dokter Rubini Mempawah, Tesis Program Studi Teknik Lingkungan Jurusan Teknik Sipil Fakultas Teknik Universitas Tanjung Pura Ponitianak.

Metcalf \& Eddy. 1991. Wastewater Engineering : Treatment,Disposal and Reuse. McGraw-Hill. New York.

Kementerian Pekerjaan Umum Direktorat Jenderal Cipta Karya. 2006. Kriteria Teknis Prasarana dan Sarana Pengolahan Air Limbah. Jakarta.

Kementerian Pekerjaan Umum Direktorat Jenderal Cipta Karya. 2008. Kebijakan dan Strategi Nasional Pengembangan Sistem Pengelolaan Air Limbah. Jakarta.

Keputusan Menteri Kesehatan Republik Indonesia Nomor 1204. 2004. Persyaratan Kesehatan Lingkungan Rumah Sakit, Departemen Kesehatan RI. Jakarta.

Keputusan Menteri Negara Lingkungan Hidup Nomor 58. 1995. Baku Mutu Limbah Cair bagi kegiatan Rumah Sakit, Kementerian Lingkungan Hidup RI. Jakarta.

Profil Rumah Sakit dan Laporan Tahunan Rumah Sakit dr. Ernaldi Bahar Kota Palembang, Provinsi Sumatera Selatan. 2013

Rhenny. 2014. Desain Istalasi Pengolahan Air Limbah (IPAL) Biofilter untuk mengolah air limbah Poliklinik UNIPA. Surabaya.

Said,NI. 2006. Teknologi Pengolahan Air Limbah Sakit dengan Sistem Biofilter
Anaerobic-Aerobic, Seminar Teknologi Pengelolaan Limbah II. Jakarta.

Tim Penyusun Karya Tulis Ilmiah Universitas Sriwijaya. 2013. Pedoman Umum Penulisan Karya Tulis Ilmiah. Universitas Sriwijaya, Palembang. 